\title{
As falas de Jerônimo: Trabalhadores, sindicatos e a historiografia da ditadura militar brasileira
}

\author{
Larissa Rosa Correa* \\ Paulo Roberto Ribeiro Fontes ${ }^{* *}$
}

Resumo: Este artigo tem como objetivo apresentar questôes e reflexôes sobre a produção historiográfica referente ao estudo dos trabalhadores e do movimento sindical brasileiro durante a Ditadura Militar (1964-1985), à luz da literatura sobre o período autoritário que abarca a chamada "história do tempo presente". Procura-se chamar a atenção para um certo apagamento da presença dos trabalhadores e suas organizaçóes representativas de classe verificada no conjunto de análises mais recentes sobre o período. Dessa forma, ao revelar as açôes das classes trabalhadoras e expor os dilemas do movimento sindical frente à política trabalhista elaborada a partir do governo do marechal Castelo Branco (19641967) e à repressão policial-militar, este estudo busca contribuir para uma melhor compreensão do cenário político instaurado em 1964. Ademais, a segunda parte do artigo apresenta um conjunto de temáticas abordadas nos estudos mais recentes realizados sobre trabalho, trabalhadores e sindicalismo na Ditadura Militar, apontando ainda para determinadas lacunas e desafios historiográficos.

Palavras-chave: Trabalhadores. Movimento sindical. Ditadura Militar. Historiografia.

\footnotetext{
* Professora do Departamento de História da Pontifícia Universidade Católica do Rio de Janeiro - PUC-Rio. Doutora em História Social pela Universidade Estadual de Campinas - UNICAMP. E-mail: larissa_correa@puc-rio.br.

${ }^{* *}$ Professor e pesquisador da Escola de Ciências Sociais da Fundação Getulio Vargas - FGV, no Rio de Janeiro. Doutor em História Social pela Universidade Estadual de Campinas - UNICAMP. Bolsista de produtividade do CNPq. E-mail: paulo.fontes@fgv.br.
} 


\section{Introdução}

No dia $1^{\circ}$ de abril de 2014, o Brasil "descomemorou" os cinquenta anos do golpe civil-militar. A data representou um importante momento para debates, publicaçóes, artigos de jornais, entrevistas e outras manifestaçôes de repúdio ao período ditatorial. Nos últimos dez anos, testemunhamos o aumento considerável do número de estudos acadêmicos sobre o autoritarismo do pós-1964. Aos poucos, os historiadores vêm se ocupando cada vez mais da chamada "história do tempo presente", lançando novos olhares sob determinados eventos dos quais muitos pesquisadores, a maioria sociólogos e cientistas políticos, já haviam se debruçado exaustivamente. Mais recentemente, a pesquisa coletiva realizada pela Comissão Nacional da Verdade (CNV) revelou novas informaçôes, suscitou uma série de questôes, bem como desconstruiu certas narrativas até então bastante enraizadas em nossa historiografia. Revelou ainda novas vítimas da repressão ditatorial - chamamos a atenção para a perseguição, tortura e morte de centenas de indígenas e camponeses - e, principalmente, reuniu e disponibilizou ao público milhares de documentos produzidos pelos serviços secretos de informaçáo e outras agências governamentais. $\mathrm{O}$ impacto da CNV na sociedade brasileira e, principalmente, no campo de estudos sobre o período autoritário, deve, e com certeza será, tema de pesquisas futuras.

Dentre os treze Grupos de Trabalho organizados pela CNV, destaca-se o de "Ditadura e Repressão aos Trabalhadores e ao Movimento Sindical" - não por acaso o último grupo a integrar a Comissão. Sua criação foi o resultado da pressão protagonizada pelas centrais sindicais para colocar o tema "trabalho e trabalhadores" na agenda de pesquisa sobre a repressão no período ditatorial. Nesse sentido, não é surpresa observar que os trabalhadores - um dos atores sociais mais expressivos da conjuntura política do pré-golpe -, têm sido razoavelmente negligenciados neste conjunto de análises mais recentes sobre o período. Nos numerosos eventos e nas atividades sobre o cinquentenário do golpe, esta ausência tem sido notável. ${ }^{1}$ Até o momento, as análises sobre memórias durante o regime militar, baseadas sobretudo nos depoimentos de militantes de esquerda oriundos do movimento estudantil, das camadas intelectuais e artísticas, assim como os estudos 
sobre a luta armada, imprensa, política econômica e o aparato repressivo, encontram-se entre os temas mais explorados sobre o período. É verdade, no entanto, que estamos observando o avanço de estudos sobre outras temáticas, como a análise das organizaçôes de direita e da colaboração ao regime militar (CORDEIRO, 2015), das questôes sobre a repressão ao movimento gay (GREEN; QUINALHA, 2014) e das trajetórias de mulheres militantes (ROSA, 2013).

A invisibilidade dos trabalhadores e dirigentes sindicais encontra-se evidente também na memória produzida sobre os mortos e desaparecidos da Ditadura. Como exemplo, podemos comparar o impacto das denúncias em torno dos assassinatos do jornalista Vladimir Herzog e do metalúrgico Manoel Fiel Filho, ambos mortos sob tortura; o primeiro em 1975 e o segundo no ano seguinte, nas dependências do DOI-Codi. Em comum, pesava sob os dois a acusação de vínculo com o Partido Comunista (PCB) e a manipulação das suas mortes justificadas como suicídio pelos policiais torturadores. Todavia, as atrocidades cometidas contra Manoel Fiel Filho, um operário da capital paulista, migrante nordestino, ainda é pouco conhecida do grande público e raramente citada nos livros didáticos. ${ }^{2}$ De forma semelhante, a trajetória do militante operário e sindicalista Virgílio Gomes da Silva, igualmente morto pela repressão sob tortura, carece ainda ser melhor explorada. "Jonas", como era conhecido na guerrilha, foi retratado no filme $O$ que é isso, companheiro?. A película de 1998, dirigida por Bruno Barreto e com roteiro baseado no livro homônimo de Fernando Gabeira, dedicou-se a narrar as açóes do sequestro do embaixador norte-americano Charles Elbrik, realizado em 1969, pelas organizaçóes guerrilheiras ALN e MR-8. $\mathrm{O}$ filme causou polêmica entre os ex-presos políticos que haviam militado com Gabeira, não apenas pelo protagonismo que o autor da obra julgou ter desempenhado, mas também pelo modo como o companheiro "Jonas" foi retratado na história. O migrante nordestino, operário e militante do $\mathrm{PCB}$, que decidiu entrar para a luta armada após o golpe, foi escolhido para ser o viláo do filme. ${ }^{3}$ Virgílio/Jonas foi retratado como um homem rude, duro, autoritário, desumano, decidido a matar sem vacilar qualquer um que estivesse bloqueando o caminho da revoluçáo. Sua postura sisuda intimidava até mesmo os seus companheiros de ação. ${ }^{4}$ 


\section{Da ausência/imobilismo à reação operária}

Este artigo tem como objetivo analisar essa ausência dos trabalhadores(as) e de suas organizaçóes nas narrativas sobre a ditadura, chamando a atenção para um conjunto de questóes que vêm sendo trabalhadas numa crescente historiografia recente sobre o tema. Procuraremos também destacar algumas das lacunas e dos desafios dessa produção, em particular no campo da história política e social do Brasil recente.

O caso de Virgílio Gomes da Silva, citado anteriormente, permite não apenas desafiarmos os velhos estereótipos construídos em torno da imagem dos trabalhadores ("feios, sujos, brutos e malvados"), mas também pode suscitar reflexóes sobre a participação dos trabalhadores na luta armada e suas relaçóes com os militantes oriundos de outros setores sociais. Como os militantes trabalhadores portadores de uma cultura própria do mundo operário e sindical lidavam com diferentes hábitos, vocabulários, leituras e modos de agir e pensar próprios dos militantes que vinham do movimento estudantil e das camadas médias? E ainda, quantos teriam participado de açóes diretas contra o regime militar, sem, contudo, terem sido reconhecidos como militantes operários? Sua identidade específica como trabalhadores era diluída ao entrar para o movimento de guerrilhas? Por outro lado, seria importante compreender o que os trabalhadores pensavam sobre as açôes da luta armada. ${ }^{5}$ Essas e outras tantas questôes sobre a relaçáo entre os mundos do trabalho e a resistência armada à ditadura ainda não foram suficientemente exploradas na literatura sobre a luta armada, uma das áreas com maior número de estudos sobre o regime militar. Novas análises talvez possam problematizar e relativizar um senso comum, lembrado por Yuri Rosa de Carvalho, que indica que aos operários, "[...] dada sua inabilidade e falta de capacidade de organização, coube o silêncio e o ostracismo; eles seriam indiretamente responsáveis pelo fracasso da resistência, pois não teriam aderido, enquanto conjunto da classe operária, à resistência contra a Ditadura" (CARVALHO, 2012, p. 340).

Com base nesses e em tantos outros exemplos, podemos afirmar que o tema trabalho, trabalhadores e movimento sindical tem caminhado à margem dos estudos sobre ditadura no Brasil. Tornou-se, 
por fim, uma temática um tanto quanto old fashion. Tal observação pode soar estranha para alguém que testemunhou a ascensão do movimento sindical nos anos 1950, passou pelo golpe de 1964 e viveu o suficiente para ver um operário metalúrgico nordestino, líder sindical, ser eleito presidente da República. Afinal, vale lembrar: o golpe civil-militar de 1964 foi, sobretudo, uma reação à ação organizada dos trabalhadores urbanos e rurais, que se mobilizaram em massa pelas reformas de base. Os militares e seus aliados civis, em particular no mundo empresarial, queriam, em grande medida, impedir o avanço da tão temida "República Sindicalista" e não foi à toa que as tropas militares comandadas pelo general Olímpio Mourão, na madrugada do dia 31 de março para o dia primeiro de abril de 1964, invadiram a Fábrica Nacional de Motores - símbolo do nacionaldesenvolvimentismo da Era Vargas - localizada estrategicamente na estrada que liga Minas ao Rio, para prender e isolar os trabalhadores. Sabemos que a vila operária da FNM, que ficava dentro da fábrica, foi invadida pelos militares no meio da madrugada. Trabalhadores e seus familiares foram retirados a pontapés de suas casas. Muitos deles considerados "subversivos de alta periculosidade" foram presos, outros fugiram ou buscaram esconderijos por tempo indeterminado. Outros, querendo manter a normalidade, tentaram trabalhar, mas foram logo impedidos de entrar na linha de produção. Os operários foram levados para o pátio e lá ficaram por longas horas encostados na parede com as mãos para cima. Alguns desmaiaram ou caíram sob o sol forte, tendo sido "acordados" por baldes de água atirados pelos militares (RAMALHO, 1989).

Mas o que teria acontecido com o restante dos trabalhadores e seus sindicatos logo no momento de deflagração do golpe? Como souberam dos acontecimentos? Quais estratégias foram traçadas? Como se deu a repressão sobre eles? E seus sindicatos, suas lideranças? Tudo o que a historiografia nos contou até bem pouco tempo atrás poderia ser resumido nas palavras do líder estudantil Vladimir Palmeira. Segundo ele, 1964 tinha lhe ensinado uma lição: "Não se pode confiar na legalidade burguesa. Perdemos em 64 porque os trabalhadores não reagiram" (VENTURA, 1988, p. 65). Em outras palavras, a ideia de náo reaçáo, de paralisia e/ou passividade dos trabalhadores diante do golpe, limitou sobremaneira os estudos sobre 
os trabalhadores. Se o presidente João Goulart procurou associar a sua imagem à dos trabalhadores no pré-64, o inverso aconteceu após o golpe. A decisão de Jango de náo reagir ao avanço das tropas militares e sua fuga silenciosa para o Uruguai tornou o movimento dos trabalhadores a sua imagem e semelhança. Estes ficaram aprisionados em interpretaçóes dedicadas a esquadrinhar as suas supostas "ausências" (de organização de classe, de consciência política, de espírito coletivo etc.).

Uma cena emblemática do famoso filme Terra em Transe, de Glauber Rocha, lançado em 1967, três anos após o golpe, reflete em grande medida o modo como o papel dos trabalhadores na ditadura foi interpretado por intelectuais, políticos, militantes de esquerda e conservadores. “O povo é Jerônimo. Fala, Jerônimo! Fala!”. Silêncio. Metralhadora dispara balas ao alto. "Não tenha medo, meu filho. Fale, você é povo", diz com condescendência o político populista. Ele suplica: "fale!". Jerônimo olha para as pessoas ao seu redor, tenta esboçar alguma palavra, mas não consegue romper o longo silêncio. Jerônimo então finalmente encara a câmara e diz: "[...] eu sou um homem pobre, um operário, sou presidente do sindicato, estou na luta das classes e acho que está tudo errado e eu não sei mesmo o que fazer. O país está numa grande crise e o melhor é aguardar a ordem do presidente". Mas a sua fala é interrompida quando as mãos de Paulo Martins, jornalista, poeta e assessor do político populista, calam a boca de Jerônimo para dizer: "Você vê o que é o povo? Um imbecil, um analfabeto, um despolitizado. Já pensaram Jeronimo no poder?”.

Afinal, por que os trabalhadores não "reagiram"? A busca pela resposta a essa pergunta influenciou parte significativa da historiografia sobre a ditadura militar brasileira e sua relação com os mundos do trabalho. Podemos dizer que, em linhas gerais, a primeira geração de intelectuais que procurou responder a esta questáo voltou suas atençóes para o período anterior ao golpe, procurando entender a construçáo do sindicalismo de estado varguista e no suposto papel subalterno das esquerdas, em particular do Partido Comunista, as origens da derrota de 1964 (RODRIGUES, 1966; RODRIGUES, 1968; MOISÉS, 1978; SOUZA MARTINS, 1979; VIANNA, 1976). Nesse sentido, as teorias do populismo, formuladas por Francisco Weffort no final dos anos 1960 e início dos anos 1970 ganharam 
enorme influência e, apesar de algumas críticas e discussôes contundentes já naquele período - ver em particular os debates entre Weffort, Maria Hermínia Tavares de Almeida e Carlos Estevam Martins (WEFFORT, 1973; 1978; ALMEIDA; MARTINS, 1973) - determinaram muito da agenda dos estudos sobre trabalhadores sobre o pré-1964, mas também os poucos estudos que começavam a aparecer sobre o período ditatorial.

O grande realce, portanto, recaia sobre as relaçóes entre sindicatos e Estado, em particular nas análises sobre o corporativismo, visto de maneira geral como a "armadilha" populista que havia enredado os trabalhadores nas teias da dominação estatal. A ditadura, ao aprofundar os mecanismos de controle corporativista, teria, por conseguinte, evidentes elementos de continuidade com o período anterior. Assim, com diferentes ênfases, trabalhos como os dos brasilianistas Kenneth Mericle (1977) e Kenneth Erickson (1979) ou da socióloga Heloísa de Souza Martins (1979) são exemplos eloquentes dessas interpretações. Assim como o são os ensaios de Argelina Figueiredo (1978) sobre as intervençôes sindicais e o livro de Maria Helena Moreira Alves (1985) que joga luz para o papel do controle do trabalho na lógica da segurança nacional vislumbrada pelos militares.

Em uma perspectiva teórica diferente, mas também marcada pela necessária compreensão do período varguista para o entendimento das políticas iniciais da ditadura em relação ao universo do trabalho, o cientista político Wanderley Guilherme dos Santos (1979) cunharia o interessante conceito de "cidadania regulada", que também influenciaria uma série de estudos, em particular sobre temas como o FGTS, a previdência social, entre outras políticas públicas na área de trabalho. Em que pese a riqueza de muitas dessas interpretaçóes, sua mirada centrada na ação do Estado de cima para baixo reforçaria, em geral, uma perspectiva de ausência, inação e subordinação dos trabalhadores e suas organizaçóes a uma lógica externa às suas próprias açóes e agências.

As análises eram razoavelmente diferentes para o intrigante sindicalismo rural articulado no período ditatorial em torno da CONTAG (Confederação Nacional dos Trabalhadores na Agricultura). Estudos sobre os canavieiros pernambucanos conduzidos em particular por antropólogos ligados ao Museu Nacional (Ligia Sigaud, 
Afrânio Garcia, Moacir Palmeira e José Sérgio Leite Lopes entre outros) e um pouco mais tarde, as análises sobre o sindicalismo rural no estado do Rio de Janeiro, feitas por cientistas sociais do CPDA da Universidade Federal Rural (Leonilde Sérvolo de Medeiros entre outros) mostravam um movimento social muito mais dinâmico e, muitas vezes capaz de ressignificar a lógica corporativista em favor dos trabalhadores, articulando lutas e ações mesmo em um contexto de repressão ditatorial. No entanto, boa parte dessas pesquisas só veio à luz em forma de livros e artigos nos anos 1980, amalgamando-se com a já consagrada produção do período sobre os chamados "novos movimentos sociais".

A literatura memorialística que emergiu com força no final dos anos 1970, durante a abertura política, reforçou um certo "apagamento" da presença dos trabalhadores na resistência ao regime militar, em particular entre o golpe e o ano de 1978. As greves dos metalúrgicos em Osasco e Contagem no ano de 1968 eram, em geral, vistas como exceçóes que comprovavam a regra (WEFFORT, 1972). O impacto das memórias de ativistas vinculados à luta armada foi predominante e ajudou a consolidar uma visão não só sobre o perfil típico dos opositores do regime (estudantes de classe média), mas também uma visão de desinteresse político, aquiescência e por vezes até de apoio ao regime, por parte dos trabalhadores. Daniel Aarão Reis, ao constatar a "notável incapacidade de articulação dos trabalhadores na ilegalidade", colocou as seguintes questóes:

Até que ponto não estaria vinculada [a inação dos trabalhadores] ao desabamento das referências políticas tradicionais? Afinal, as lideranças, as formas de luta, os tipos de organização que haviam marcado a evolução do movimento popular, em suma, todo um universo de representaçóes e práticas desaparecera sem deixar vestígios. A dispersão e a desmoralização não seriam resultados inevitáveis, ao menos por um certo período? Por outro lado, em que medida as políticas do novo regime não estariam criando novas divisóes entre os oprimidos e explorados? (REIS, 1990, p. 64) 
Na sequência, Reis chama a atenção para a evolução diferenciada das curvas do salário mínimo e do salário médio entre os chamados bolsôes de miséria absoluta e os setores industriais beneficiados pelo mercado interno. Tais discrepâncias vivenciadas pelos trabalhadores, afirmou o autor, náo foram consideradas pelos comunistas, que teriam insistido em adotar como estratégia política os discursos que evocavam as condiçóes comuns que unificavam a classe trabalhadora. Nesse sentido, o autor questiona como se dariam as diferenças entre trabalhadores dos setores "dinâmicos" da economia, que gozavam de um regime próprio de trabalho, e os empregados nos setores chamados de "tradicionais" e das empresas estatais. Teriam setores importantes das próprias classes populares sido atraídos por um novo estilo de vida proposto pelo regime militar? Em suma, Reis aponta para a heterogeneidade da classe trabalhadora para compreender o suposto tímido papel desempenhado pelos trabalhadores no combate à ditadura. Tal heterogeneidade aprofundar-se-ia durante o chamado "milagre econômico", uma vez que a política econômica do regime gerou latente aumento da desigualdade social e teve como meta beneficiar as camadas médias, mas também ampliou as diferenças salariais e de status entre os próprios trabalhadores.

A inação teria dado lugar à agência. Durante o movimento de redemocratização travado no final da década de 1970, os pesquisadores passaram a enfatizar a capacidade de organização e mobilização autônoma dos trabalhadores, isto é, sem a dependência dos sindicatos oficiais atrelados ao sistema corporativista ou de políticos "populistas". As grandes greves iniciadas no ABC paulista em 1978, movimento que logo se espalharia por todo o país, tornaram-se o símbolo da mudança da percepçáo sobre o papel da classe trabalhadora e sua relação com o regime autoritário. Os atos massivos e contestatórios, o evidente protagonismo dos trabalhadores e uma certa surpresa generalizada contribuíram para uma visão que percebia aquele momento como único na história do Brasil, um verdadeiro divisor de águas que estaria rompendo simultaneamente com o já distante passado "populista" do pré-1964 (TROYANO, 1978; COSTA, 1986; entre outros) e com o recente passado de subordinação e imobilismo dos trabalhadores durante a ditadura. 
Como sabemos, a ideia da "novidade" prevaleceu na leitura acadêmica e política daquele período. Os trabalhadores estariam criando um "novo sindicalismo" e atuando em "novos movimentos sociais", superando a tradição populista de subordinação ao Estado, mobilizando-se massivamente nos locais de trabalho e bairros e atuando de maneira independente e autônoma. A nova fase de ascensão e efervescência do movimento operário, assim como o seu engajamento na luta pela redemocratização do país, marcou uma nova geração de estudiosos. Muitos deles escreveram sobre o "novo sindicalismo" bastante inspirados nas açôes pelas quais eles tiveram a oportunidade de testemunhar (ALMEIDA, 1983; HUMPHREY, 1979; BARGAS, 1983; MARONI, 1982).

Apesar dos exageros e de uma certa ingenuidade, a produção das ciências sociais sobre a atuação dos trabalhadores nos estertores da ditadura foi não apenas numerosa (as greves do $\mathrm{ABC}$ estão, segundo o historiador norte-americano John French, entre as mais estudadas em todo o mundo), mas, em geral, de grande qualidade, marcando uma era dourada de estudos sobre as classes trabalhadoras e os movimentos sociais no final dos anos 1970 e na década de $1980 .^{7}$ É verdade que os historiadores entraram um tanto tardiamente na análise específica sobre aquele período. As greves da redemocratização parecem ter inspirado os historiadores a analisar um outro período de suposta autonomia e prevalência das práticas classistas - o início do século XX, em particular a atuação dos anarquistas e sindicalistas revolucionários (HARDMAN, 1983; MARAM, 1979; HALL; PINHEIRO, 1979, entre outros).

Embalados pela efervescência do movimento organizado dos trabalhadores e pelo clima de redemocratização da época, esses pesquisadores tenderam, em geral, a ver aquele fenômeno como um raio em céu azul. No entanto, sabemos que o chamado "novo sindicalismo" não surgiu da noite para o dia, foi, de fato, resultado de uma luta silenciosa e de uma resistência cotidiana travada no espaço fabril, nos locais de trabalho e moradia, frequentemente às margens dos sindicatos, nas franjas da repressão. Embora essas divisóes entre o "novo" e o "velho" sindicalismo tenham sido relativizadas e questionadas (SANTANA, 1998; BADARÓ, 1998), ainda precisamos compreender as condiçóes que possibilitaram a eclosão 
do "novo sindicalismo". Há, por exemplo, poucos estudos dedicados a compreender a formação e a trajetória das oposiçóes sindicais para além da atuação da Oposição Sindical Metalúrgica de São Paulo, aliás, ainda não analisada suficientemente. ${ }^{8} \mathrm{E}$ mesmo a amalgama entre os discursos autonomistas formatados pela Igreja Católica e as perspectivas obreiristas e antiburocráticas que proliferaram no movimento operário internacional entre os anos 1960 e 1970 ainda náo foi suficientemente explorada pela literatura especializada.

Nesse sentido, destaca-se o livro do historiador Antonio Luigi Negro que buscou analisar a política econômica e trabalhista do nacional desenvolvimentismo da Era Vargas até o final da década de 1960. Em Linhas de Montagem (2004), o autor descontrói a ideia de que os trabalhadores migrantes seriam incapazes de desenvolver um movimento coletivo fabril de reivindicaçôes e luta operária. Ao observar as mudanças políticas e econômicas instauradas após o golpe, o autor desvelou uma série de atividades de resistência dos trabalhadores travadas no espaço fabril das companhias multinacionais montadoras de automóveis da região do $\mathrm{ABC}$ paulista.

Assim, o impacto do "novo" parece ter sido tão forte que obscureceu a análise sobre os mundos do trabalho no Brasil no período da ditadura até a eclosáo das grandes greves. Quando muito eram analisados como um preâmbulo. De modo geral, chama a atenção o pouco número de publicaçóes acadêmicas sobre o movimento sindical ou o sobre o universo do trabalho em geral naquele período, especialmente entre 1964 e 1978. Além disso, o caráter repressivo e controlador do regime, que praticamente procurava tornar os sindicatos brasileiros uma extensão do Estado, pode ter dado a impressão de que não havia nada de interessante a ser estudado naquele período, salvo as esparsas manifestaçóes de resistência por parte da classe trabalhadora. Dessa forma, a ideia de que o sindicalismo brasileiro adormeceu em 1964, teve um espasmo em 1968 e acordou agitado dez anos depois - quando o chamado "novo sindicalismo" emergiu - ainda permanece, embora alguns trabalhos publicados na última década tenham começado a desconstruir essa ideia. 


\section{O alargamento do campo historiográfico, lacunas e desafios}

Os trabalhos de José Ricardo Ramalho (1989), Elina Pessanha (1985), Antonio Luigi Negro (2004) e Marco Aurélio Santana (2001) dedicados à análise do sindicalismo metalúrgico após o golpe na Baixada Fluminense, Niterói, ABC Paulista e Rio de Janeiro apontaram para caminhos muito promissores e inspiradores que permitem não apenas relativizar as distâncias entre as "velhas" e "novas" práticas sindicais, mas também evidenciar uma série de resistências cotidianas ou mesmo paralisaçóes e protestos "apagados" da história. Esses estudos enfatizaram ainda a importância das conexóes entre os locais de trabalho e as comunidades operárias. As pesquisas sobre a Oposição Sindical Metalúrgica de São Paulo (FARIAS, 1986; BATISTELA, 2010) também contribuíram no mesmo sentido.

A forte tradição de estudos sobre os trabalhadores rurais tem permitido que, recentemente, possamos saber muito mais sobre a memória camponesa e os intricados mecanismos de colaboração entre Estado e latifundiários nos processos de repressão e apropriação de terras em todo o país. O já mencionado sofisticado trabalho de pesquisadores como Leonilde Medeiros, Moacir Palmeira, Marta Ciocari, Cliff Welch e seus orientandos, entre outros, além de alargar o conhecimento acadêmico tem tido um importante impacto político, com fundamental participaçáo por exemplo na Comissáo da Verdade Camponesa, que apresentou um detalhado relatório paralelo ao da $\mathrm{CNV}^{10} \mathrm{Um}$ outro desdobramento promissor desses trabalhos tem sido a aproximação dos estudos sobre trabalhadores rurais e urbanos, durante muito tempo, confinadas em campos disciplinares com pouco diálogo. ${ }^{11}$

No mundo urbano, como vimos, a ênfase nas análises centradas na atuação do sindicalismo metalúrgico é evidente (exemplos em: NEGRO, 2010; ABRAMO, 1999; PARANHOS, 1999), mas ainda sabemos pouco sobre processos semelhantes em outras categorias urbanas importantes, com forte poder de barganha com os patróes e de mobilização. Há, é verdade, alguma literatura sobre trabalhadores químicos e bancários (ver, por exemplo CORREAA, 2014; BLASS, 1992; GUIMARÁES, 1990), cujos estudos pareciam confinados ao período anterior aos anos 1960 . Também os trabalhadores têxteis começam a ser "redescobertos" como na recente tese de Felipe Ribeiro 
(2015), que, ao abordar os tecelóes e tecelãs (bem como os trabalhadores rurais) em Magé, uma das "Moscouzinhas" brasileiras, mostrou como as lembranças da repressão e da violência policial marcaram a memória local por décadas. Ainda assim, nosso conhecimento sobre categorias vitais da atividade econômica durante o regime militar, como os petroleiros ou particularmente numerosas, como os trabalhadores da construção civil, ainda é escasso. ${ }^{12}$ Os estudos sobre trabalhadores dos setores de serviços, como comerciários ou funcionários públicos é mais rarefeito ainda. Mas, para além das categorias, chama a atenção o pouco número de estudos sobre categorias e sindicatos em regiốes fora do eixo Rio-São Paulo, com foco no período autoritário. ${ }^{13}$

O estudo sobre greves na ditadura, em particular entre 1964 e 1978 - embora em número reduzido em comparação ao período pré-1964 - é uma mostra ainda mais evidente da concentração geográfica das análises sobre a história do trabalho no Brasil. Ainda carecemos de um levantamento sobre protestos, paralisaçóes e greves durante o regime militar em todo o país. Apesar disso, interessantes estudos monográficos começam a emergir. Alguns pesquisadores, por exemplo, têm se lançado o desafio de revisitar o ano de 1968, não aquele do maio francês ou da intelectualidade artística da zona sul carioca, mas o dos operários e das periferias da grande São Paulo. Por décadas, as greves de Osasco e Contagem ficaram conhecidas pelo seu caráter espontaneísta e pela falta de organização política suficiente, motivo que teria levado o movimento paredista ao fracasso, visto pela sua curta duraçáo, conforme caracterizou Francisco Weffort (1972). Todavia, ainda conhecemos pouco sobre os meandros desse movimento, as relaçóes entre os operários e os militantes do movimento estudantil e da luta armada, que optaram pela militância na fábrica, o papel do sindicato dos metalúrgicos e dos moradores de Osasco. Recentemente, o trabalho de Marta Rovai (2012) sobre a memória dos habitantes da cidade, com ênfase na experiência das mulheres, contribuiu para iluminar como os trabalhadores grevistas, compreendida pela atuação de toda a família, participaram do movimento, bem como a repressão que se sucedeu após a greve. Os depoimentos revelaram o trauma deixado pela repressão que se sucedeu depois a paralisação e o estigma que caiu sobre os moradores. 
A questão da repressão policial-militar aos trabalhadores praticada dentro e fora das fábricas, assim como no campo, no período ditatorial, demanda uma atenção particular. Da mesma forma, argumentamos pela necessidade de construir um aparato teóricometodológico próprio para entender os significados das açóes de resistência ao abordar a repressão exercida sob os trabalhadores(as) em contextos específicos de autoritarismo. Só assim poderemos compreender o impacto profundo das ditaturas na vida dos trabalhadores. Nesse sentido, seria importante a elaboração de estudos dedicados a compreender como a classe trabalhadora vivenciou as açôes de repressão (tanto estatal quanto patronal), assim como a violência policial e privada no seu cotidiano. Afinal, vivendo sob constante estado de insegurança estrutural, o que tinha um(a) trabalhador(a) a perder ao entrar na militância política ou quando decidia simplesmente enfrentar os abusos patronais? ${ }^{14} \mathrm{O}$ risco de perder o emprego e náo ser capaz de dar provimentos a família; o risco de ser "fichado" no Deops e entrar para a "lista negra" das empresas; o risco de ser preso(a) e torturado(a) e envolver toda a família; o risco de ser morto e seu corpo nunca mais aparecer. Ainda que pesassem todas as medidas repressivas e o medo se espalhasse pelas linhas de produção, não foram poucos os operários(as) que arriscaram as suas vidas ao distribuir folhetos em frente aos portóes de fábrica, a se levantar em uma assembleia sindical e pedir a palavra para denunciar o regime, diante de policiais infiltrados (sendo a trajetória de Olavo Hansen uma das mais conhecidas, PEREIRA NETO, 2013).

Afinal, o que sabemos sobre a vida dos trabalhadores no final da década de 1960 e nos anos 1970? Sabemos, por exemplo, que, em 1963, para comprar-se a cesta alimentar no município de Sáo Paulo, eram necessárias 98 horas e 20 minutos de trabalho. Dez anos depois, era preciso trabalhar 147 horas e 04 minutos para se adquirir a mesma cesta alimentar e, no final do regime militar, os trabalhadores eram obrigados a trabalhar 194 horas e 38 minutos para comprar a mesma ração essencial mínima (COSTA, 1997). Mas o que dizer sobre a cultura operária forjada em meio ao "milagre econômico" e os grandes fluxos migratórios que se instalaram nas periferias das grandes cidades do sudeste brasileiro? De que forma os trabalhadores urbanos e rurais vivenciaram a ditadura? Quais 
estratégias cotidianas foram criadas para sobreviver à repressão sistemática instaurada nas fábricas e nos locais de trabalho em geral? Qual o impacto das grandes obras e dos projetos de desenvolvimento para os mundos do trabalho em diversas regióes do país?

Por outro lado, não podemos nos esquecer daqueles que viram o regime ditatorial com simpatia, como bem observou Reis (1990), já citado neste artigo. Muitos trabalhadores/as, nos embalos do "milagre econômico", beneficiaram-se com o crescimento econômico e com o crescimento dos postos de trabalho. Embora a política econômica dos militares tenha se baseado na exploração aguda da mão de obra barata, com base no arrocho salarial e na eliminação de direitos, muitos migrantes das zonas rurais souberam aproveitar as chances que se abriram com o aquecimento da economia, principalmente na área da construção civil e de serviços. Entre os anos de 1969 a 1973, período do "milagre econômico", muitos operários/as compartilharam, junto com os setores das classes médias, do sentimento ufanista que tomou conta do Brasil, acreditaram no "Brasil do futuro". Cabe, portanto, compreendermos os motivos do apoio desses grupos de trabalhadores ao regime, a participação deles nos sindicatos e em outras entidades civis, suas relaçóes com os empregadores e sua atuação nos locais de trabalho e na Igreja. A ditadura, inclusive, não ficou alheia a esse processo e tomou medidas concretas para angariar o apoio do mundo do trabalho. Parece surpreendente, mas muitos direitos trabalhistas e de sindicalização foram outorgados para trabalhadoras domésticas e rurais, entre outros, em pleno auge da repressão do ditador Médici. ${ }^{15}$ Eis um campo de estudo onde ainda sabemos quase nada e do qual pesquisas interessantes poderão emergir.

Não obstante a historiografia produzida nas décadas de 1970 e 1980, as relaçóes entre trabalhadores, sindicatos e Estado têm sido revisitada. Munidos de grandes conjuntos documentais disponibilizados pelas cortes trabalhistas, ainda que em estado de preservação precária, essa nova geração de pesquisadores tem realizado análises sistemáticas e quantitativas sobre o papel do Estado nas relaçóes de trabalho e o uso do aparato burocrático estatal por parte dos trabalhadores. Nos últimos dez anos, podemos encontrar uma extensa bibliografia sobre o papel da Justiça do Trabalho nos períodos pré e pós-1964, tendo os processos trabalhistas se tornado uma fonte de 
grande valor histórico, devido à sua riqueza e ao seu detalhamento de informaçóes sobre os trabalhadores reclamantes, suas demandas, seu contrato de trabalho, permitindo até mesmo desvelar aspectos importantes do cotidiano dos trabalhadores no chão de fábrica ou na lida do campo. ${ }^{16}$ Esses estudos têm aberto novas perspectivas sobre a atuação do aparelho estatal, desafiando as visóes monolíticas sobre o Estado ao enfatizar sua heterogeneidade e disputas internas. Ainda que com extrema dificuldade de acesso às fontes, temos também tido avanços sobre o papel do Ministério do Trabalho durante a Ditadura e sua relação com o Poder Executivo. Em estudo recente, Heliene Nagazava (2015) mostrou como o principal ministério do período Vargas-Goulart, o coração do trabalhismo, foi sendo sistematicamente desmontado pelos ministérios da Fazenda e do Planejamento, condutores da política econômica, a partir do governo de Castelo Branco (1964-1967). Todavia, embora o Ministério do Trabalho tenha começado a ser estudado, sabemos bem pouco sobre outras agências estatais tanto em nível federal, quanto local e também pouco sobre a fundamental previdência social. Vale destacar que esses pesquisadores têm desempenhado papel fundamental na luta pela preservação das fontes judiciais e ministeriais, militando contra o descarte desses conjuntos documentais perante os órgãos responsáveis pela sua guarda.

Outro campo em expansão na área dos estudos sobre ditadura militar brasileira e trabalho é o da análise das relaçóes internacionais no sindicalismo brasileiro. Pesquisadores como Cliff Welch (1995), Antonio Luigi Negro (2004) e Larissa Corrêa (2013) dedicaram-se a mostrar o papel do sindicalismo norte-americano no período anterior e posterior ao golpe de Estado, mostrando as suas articulaçóes com sindicalistas conservadores brasileiros, a construção das redes de contatos e informaçóes travadas entre dirigentes, especialistas em relações de trabalho, governos norte-americano e brasileiro e suas respectivas embaixadas. Ainda sobre a atuaçáo dos sindicalistas conservadores, os trabalhos desenvolvidos pelo GT Trabalhadores da CNV e a abertura dos arquivos do SNI, têm impulsionado a realização de pesquisas sobre a atuação dos interventores nos sindicatos e suas relaçôes com entidades sindicais estrangeiras (CORREA $\hat{E}, 2013)$. Na área da memória sobre o regime militar, testemunhamos um crescimento de autobiografias escritas por ex-dirigentes sindicais e militantes políticos de esquerda 
vinculados à área do trabalho, e até mesmo de quadros importantes do governo Goulart derrubados pelos militares, como foi o caso da autobiografia do ex-ministro do trabalho Almino Affonso, lançada recentemente (AFFONSO, 2014), assim como o do líder sindical ferroviário Raphael Martinelli (2014). ${ }^{17}$ Nesse sentido, a série de depoimentos de ex-sindicalistas e militantes operários e rurais colhidos no processo da Comissão Nacional da Verdade e de suas congêneres nos estados e municípios constitui material de grande riqueza para o futuro estudo de trajetórias nos mundos do trabalho. ${ }^{18}$

\section{Consideraçóes finais}

Embora em um momento de efervescência, a historiografia sobre os mundos do trabalho na ditadura militar brasileira, ainda necessita enfrentar uma série de desafios. Podemos citar rapidamente a carência de estudos que envolvam as análises de gênero e étnico-raciais nos mundos do trabalho (questão, aliás, válida para toda a historiografia do trabalho no Brasil); o trabalho indígena em diversas regiôes do país, especialmente no Centro-Oeste e Norte; o impacto ambiental da política nacional-desenvolvimentista autoritária conduzida pelos militares, principalmente no período do chamado "milagre econômico", ${ }^{19}$ sendo a denúncia dos abusos trabalhistas e as violações de direitos humanos e ambientais cometidas pela Volkswagen em sua fazenda localizada no Pará um exemplo e ponto de partida bastante promissor. ${ }^{20} \mathrm{Da}$ mesma forma, as análises sobre o impacto das grandes migraçóes e dos processos de urbanização ainda não foram suficientemente mensuradas; assim como a responsabilizaçáo empresarial: papel das empresas na repressão direta e em questóes como condiçôes e acidentes de trabalho (e aqui mais uma vez o GT dos Trabalhadores da CNV lança nova luzes nesta questão). Outro desafio que se coloca para os pesquisadores do trabalho e dos regimes autoritários da Guerra Fria é o de pensar as ditaduras e os mundos do trabalho no contexto da América Latina, realizando comparaçôes e necessárias conexôes. 


\section{THE WORDS OF JERÔNIMO: WORKERS, UNIONS AND THE HISTORIOGRAPHY OF THE BRAZILIAN MILITARY DICTATORSHIP}

Abstract:This article analyses the recent Brazilian scholarship on workers and trade unions during the Military Dictatorship (1964-1985). It emphasizes the relative absence of studies and the neglecting of the importance of the workers and their organization in the main narratives about this period. By stressing the working-class agency and the dilemmas of the labor movement was facing with the economic policies of the Military as well as the fierce repression, this study aims to contribute to a better understanding of the political scenario after 1964 . Furthermore, the second part of the article presents the themes and subjects of the more recent studies about the workers and the labor movement during the military regime. It also points out the blind spots and challenges for this contemporary historiography.

Keywords: Workers. Labor movement. Unions. Military Dictatorship. Historiography.

\section{Notas}

${ }^{1}$ Um exemplo representativo da escassez de análises sobre o movimento sindical e o mundo dos trabalhadores nos estudos dedicados ao período da ditadura militar pode ser observado na coletânea organizada por Daniel Aarão Reis, Marcelo Ridenti e Rodrigo Patto Sá Motta, 2014. O único artigo dedicado ao tema trata da questão do "novo sindicalismo", abordando, dessa forma, apenas o período final do regime.

${ }^{2}$ Ver o documentário Perdão Mister Fiel - o operário que derrubou a ditadura no Brasil, de Jorge Oliveira, 2012.

${ }^{3}$ Para saber mais sobre a trajetória de Virgílio Gomes da Silva, ver: (PIMENTA; TEIXEIRA, 2009).

${ }^{4}$ As críticas feitas por ex-presos políticos, intelectuais e jornalistas em relação ao modo como Virgílio foi retratado na película foram publicadas em uma pequena coletânea destinada a defender a honra e a história de Virgílio, (REIS, 1997).

${ }^{5}$ Parte dessas questôes são abordadas em: (CARVALHO, 2012). Ver também: (FREDERICO, 1987).

${ }^{6}$ Terra em transe, filme de Glauber Rocha, de 1967.

${ }^{7}$ Para um recente balanço bibliográfico dos estudos sobre o novo sindicalismo, ver: (OLIVEIRA; LADOSKY, 2014).

${ }^{8}$ Estudo de maior fôlego é o de Batistoni (2010). 
${ }^{9}$ Ver também, do mesmo autor, Nas origens do 'Novo Sindicalismo': o maio de 59, 68 e 78 na indústria automobilística, In: Rodrigues (1999).

${ }^{10} \mathrm{O}$ relatório da Comissão da Verdade Camponesa está disponível em: http:// r1.ufrrj.br/cpda/blog/2015/01/21/relatorio-da-comissao-camponesa-da-verdade-esta-disponivel-para-download/. Acesso em: $10 \mathrm{dez} .2015$.

${ }^{11}$ Ver exemplo em Felipe Ribeiro (2015)

${ }^{12}$ Embora não sejam o foco de seu trabalho, as relaçôes de trabalho no setor da construção civil durante a ditadura são abordadas no estudo pioneiro de Pedro Henrique Pedreira Campos (2015).

${ }^{13}$ Nesse sentido, o dossiê "Trabalhadores e ditadura", organizado por Antonio Luigi Negro, Larissa Rosa Corrêa e Paulo Fontes e publicado na Revista Mundos do Trabalho, v. 6, n. 11, 2014, buscou minimizar essa lacuna, reunindo um conjunto de trabalhos que abarcam ampla diversidade regional e temática.

${ }^{14}$ Ao utilizarmos o conceito de "insegurança estrutural" nós nos referimos ao trabalho de Mike Savage, ver: SAVAGE, Mike. "Classe e história do trabalho". In: BATALHA, Cláudio H. M.; SILVA, Fernando Teixeira da; FORTES, Alexandre. Culturas de classe: identidade e diversidade na formação do operariado. Campinas: Ed. UNICAMP, 2004.

${ }^{15}$ Um exemplo é a lei que instituiu o Pro Rural, garantindo os direitos de pensão e aposentadoria para os trabalhadores rurais, decreto no 69.919, assinado em 11 de janeiro de 1972, pelo governo Médici. Já a lei no 5.859, de 11 de dezembro de 1972, reconheceu alguns direitos trabalhistas às empregadas domésticas.

${ }^{16}$ Ver exemplos em: Dabat e Rogers (2012); Montenegro (2013).

${ }^{17}$ Cabe destacar ainda o trabalho realizado pela ONG Intercâmbio, Investigação, Estudos e Pesquisas (IIEP), em particular de seu diretor Sebastiấo Neto, que tem realizado uma série de entrevistas e angariado vasto material sobre os trabalhadores metalúrgicos de São Paulo durante a ditadura. Um dos resultados deste trabalho é o impressionante livro Investigação Operária. Empresários, militares e pelegos contra os trabalhadores, publicado em 2014.

${ }^{18}$ Ver Relatório do GT Trabalhadores da CNV, entregue em 2014. Disponível em: https://trabalhadoresgtcnv.wordpress.com/. Acessado em 10 dez. 2015.

${ }^{19} \mathrm{Um}$ dos poucos estudos a respeito é de Frank Meyer. "Cidades-empresa numa cadeia produtiva transnacional: dimensões sociais e ambientais da produção de alumínio em Porto Trombetas, Brasil, e Årdal, Noruega”. Revista Mundos do Trabalho, v. 6, n.11, 2014, p. 107-127.

${ }^{20}$ ACKER, Antoine. 'O maior incêndio do planeta': como a Volkswagen e o regime militar brasileiro acidentalmente ajudaram a transformar a Amazônia em uma arena política global. Revista Brasileira de História, v. 34, n. 68, jul/dez., 2014. 
As falas de Jerônimo: Trabalhadores...

\section{Referências}

AFFONSO, Almino. 1964 na visão do ministro do Trabalho de João Goulart. São Paulo: Imprensa Oficial/Fundap, 2014.

ALMEIDA, Maria Hermínia Tavares de; MARTINS, Carlos Eduardo. Modus in rebus: partidos e classes na queda do Estado Novo. São Paulo: Cebrap, [1973]. Mimeografado.

ALVES, Maria Helena Moreira. Estado e oposição no Brasil (1964-1984). 3. ed. Petrópolis: Vozes, 1985.

BATISTONI, Maria Rosângela. Confronto operário. A Oposição Sindical Metalúrgica nas greves e nas comissóes de fábrica de São Paulo (1978-1980). São Paulo: Núcleo Piratininga de Comunicação, 2010.

CAMPOS, Pedro Henrique Pedreira. Estranhas catedrais. As empreiteiras brasileiras e a Ditadura Civil-Militar. Rio de Janeiro: Editora da UFF/Faperj, 2014.

CARVALHO, Yuri Rosa de. O movimento operário e a Ditadura Civil-Militar: resistência, luta armada e negociação. Revista Latino-Americana de História, v. 1, n. 3, 2012.

CORDEIRO, Janaina. A ditadura em tempos de milagre. Comemoraçôes, orgulho e consentimento. Rio de Janeiro: FGV/Faperj, 2015.

CORRÊA, Larissa Rosa. Disseram que voltei americanizado: relaçóes sindicais Brasil e Estados Unidos na ditadura militar (1964-1978). Tese (Doutorado), IFCH - Unicamp. Campinas: Unicamp, 2013.

. Os 'inimigos da pátria': repressão e luta dos trabalhadores do Sindicato dos Químicos de São Paulo (1964-1979), Revista Brasileira de História, v. 34, n. 67, 2014.

COSTA, Edmilson. A politica salarial no Brasil (1964-1985): 21 anos de arrocho salarial e acumulação predatória. São Paulo: Boitempo, 1997.

. Estado e Controle Social no Brasil. São Paulo: T. A. Queiroz Editor, 1986.

DABAT, Christine Rufino; ROGERS, Tom D. A Peculiarity of Labor in this Region. Workers' Voices in the Labor Court Archive at the Universidade Federal de Pernambuco. Latin American Research Review, v. 47, 2012, p. 163-68.

ERICKSON, Kenneth Paul. Sindicalismo no Processo Politico no Brasil. São Paulo, Brasiliense, 1979.

FARIA, Hamilton J. B. de. A experiência operária nos anos de resistência: a Oposição Metalúrgica de Sáo Paulo e a dinâmica do movimento operário 
(1964-1978). São Paulo: Dissertação (Mestrado), Programa de Pós-Graduação em Ciências Sociais, PUC-SP, 1986.

FIGUEIREDO, Argelina Cheibub. Intervençôes sindicais e o "novo sindicalismo". Dados, v. 17, 1978, p. 136-45.

FREDERICO, Celso. (Org.). A esquerda e o movimento operário. Vol I. A resistência à ditadura (1964-1971). 1. ed. São Paulo: Novos Rumos, 1987.

GREEN, James N.; QUINALHA, Renan (Orgs.). Ditadura e homossexualidades: repressão, resistência e a busca da verdade. São Carlos: EdUFSCar, 2014.

GUIMARĀES, Antonio Sérgio Alfredo. "A gestão do trabalho na indústria petroquímica (a forma geral e a variante paternalista)". Caderno $C R H$, Salvador: CRH, n. 12, 1990.

HALL, Michael M; PINHEIRO, Paulo Sérgio (Org.). A Classe Operária No Brasil, 1889-1930: Documentos. Vol. 1: O Movimento Operário. São Paulo: Alfa-Ômega, 1979.

IIEP. Investigação Operária. Empresários, militares e pelegos contra os trabalhadores. São Paulo: IIEP, 2014.

MERICLE, Kenneth S. Corporatist Control of Working Class: Authoritarian Brazil since 1964. In: MALLOY, James (Ed.). Authoritarism and Corporativism in Latin America. Pittsburgh, University of Pittsburgh Press, 1977.

MONTENEGRO, Antonio. Trabalhadores rurais e Justiça do Trabalho em tempos de regime civil-militar.. In: GOMES, Angela de Castro; SILVA, Fernando Teixeira da (Orgs.). A Justiça do Trabalho e sua história. Campinas: editora da Unicamp, 2013, p. 303-348.

NAGASAVA, Heliene Chaves. "O sindicato que a ditadura queria": o Ministério do Trabalho no governo Castelo Branco (1964-1967). Dissertação (Mestrado), CPDOC/FGV. Rio de Janeiro, 2015.

NEGRO, Antonio Luigi. Linhas de Montagem. O industrialismo nacional-desenvolvimentista e a sindicalizaçáo dos trabalhadores. São Paulo: Boitempo/Fapesp, 2004.

. Nas origens do 'Novo Sindicalismo': o maio de 59, 68 e 78 na indústria automobilística. Iin: RODRIGUES, Iram J. (Org.). O Novo Sindicalismo. Vinte anos depois. Petrópolis: Vozes/Educ/Unitrabalho, 1999.

OLIVEIRA, Roberto Veras de; LADOSKY, Mário Henrique. O "novo sindicalismo" pela ótica dos estudos do trabalho. Revista Mundos do Trabalho, v. 6, n. 11, 2014. PEREIRA NETO, Murilo Leal. Olavo Hansen. São Paulo: Expressão Popular, 2013. 
PIMENTA, Edileuza; TEIXEIRA, Edson. Virgílio Gomes da Silva: de retirante a guerrilheiro. São Paulo: Plena Editorial /Núcleo Memória, 2009.

RAMALHO, José Ricardo. Estado-Patrão e luta operária. O caso FNM. Rio de Janeiro: Paz e Terra, 1989.

REIS, Daniel Aarão et al. Fatos e versóes: o sequestro da história. São Paulo: Perseu Abramo, 1997. . A revolução faltou ao encontro. São Paulo: Brasiliense, 1990.

REIS, Daniel Aarão; RIDENTI, Marcelo; MOTTA, Rodrigo Patto Sá. A ditadura que mudou o Brasil. 50 anos do golpe de 1964. Rio de Janeiro: Zahar, 2014.

RIBEIRO, Felipe Augusto dos Santos. A foice, o martelo e outras ferramentas de ação política: os trabalhadores rurais e têxteis de Magé/RJ (1956-1973). Tese (Doutorado), Centro de Pesquisa e Documentação, FGV. Rio de Janeiro, 2015.

RODRIGUES, José Albertino. Sindicato e desenvolvimento social no Brasil. São Paulo: Difel, 1968.

RODRIGUES, Leôncio Martins. Conflito industrial e sindicalismo no Brasil. São Paulo: Difusão Europeia do Livro, 1966.

ROSA, Susel Oliveira da. Mulheres, ditaduras e memórias. Sáo Paulo: Intermeios/ Fapesp. 2013.

ROVAI, Marta Gouveira de Oliveira. Osasco 1968: A greve no feminino e no masculino. Tese (Doutorado), FFLCH/Usp. São Paulo, 2012.

SANTOS, Wanderley Guilherme dos. Cidadania e justiça. Rio de Janeiro: Campus, 1979.

SOUZA MARTINS, Heloísa. O Estado e a burocratização do sindicato no Brasil. São Paulo: Hucitec, 1979.

TROYANO, Annez. Estado e sindicalismo. São Paulo: Símbolo, 1978.

VENTURA, Zuenir. 1968: o ano que não terminou. 3. ed. Rio de Janeiro: Objetiva, 2013.

VIANNA, Luiz Werneck. Liberalismo e sindicato no Brasil. Rio de Janeiro: Paz e Terra, 1976.

WEFFORT, Francisco. Participação e conflito industrial: Contagem e Osasco, 1968. Estudos Cebrap, Caderno 5, 1972.

WEFFORT, Francisco Correa. Origens do sindicalismo populista no Brasil: a conjuntura do após-guerra. Estudos Cebrap, São Paulo, n. 4, p. 65-105, 1973. 
. Dejémonos de farsas intelectuais e resistência democrática... inutiles. Sáo Paulo: Cebrap, [197-].

. O populismo na politica brasileira. Rio de Janeiro: Paz e Terra, 1978.

WELCH, Clifford Andrew. Labor Internationalism: U.S. Involvement in Brazilian Unions, 1945-1965. Latin American Research Review, v. 30, n. 2, 1995.

Recebido em: 14 / 12 / 2015 मी

Aprovado em: 15 / 03 / 2016 